\title{
"The effect of it-transformation of the country's financial potential during the post-conflict reconstruction"
}

\begin{tabular}{|c|c|c|}
\hline \multirow{4}{*}{ AUTHORS } & \multicolumn{2}{|c|}{ Nataliya Vyhovska (D https://orcid.org/0000-0001-7129-6169 } \\
\hline & \multicolumn{2}{|c|}{ R http://www.researcherid.com/rid/B-2434-2018 } \\
\hline & \multicolumn{2}{|c|}{ Andrii Polchanov (D) https://orcid.org/0000-0001-6019-9275 } \\
\hline & \multicolumn{2}{|c|}{$\begin{array}{l}\text { Serhii Frolov } \\
\text { Yevhenii Kozmenko (D https://orcid.org/0000-0003-2721-2997 }\end{array}$} \\
\hline ARTICLE INFO & \multicolumn{2}{|c|}{$\begin{array}{l}\text { Nataliya Vyhovska, Andrii Polchanov, Serhii Frolov and Yevhenii Kozmenko } \\
\text { (2018). The effect of it-transformation of the country's financial potential during the } \\
\text { post-conflict reconstruction. Public and Municipal Finance, 7(3), 15-25. } \\
\text { doi:10.21511/pmf.07(3).2018.02 }\end{array}$} \\
\hline DOI & \multicolumn{2}{|c|}{ http://dx.doi.org/10.21511/pmf.07(3).2018.02 } \\
\hline RELEASED ON & \multicolumn{2}{|l|}{ Tuesday, 04 December 2018} \\
\hline RECEIVED ON & \multicolumn{2}{|l|}{ Friday, 19 October 2018} \\
\hline ACCEPTED ON & \multicolumn{2}{|l|}{ Thursday, 29 November 2018} \\
\hline & \multicolumn{2}{|l|}{$((c)) E Y$} \\
\hline LICENSE & \multicolumn{2}{|c|}{$\begin{array}{l}\text { This work is licensed under a Creative Commons Attribution } 4.0 \text { International } \\
\text { License }\end{array}$} \\
\hline JOURNAL & \multicolumn{2}{|l|}{ "Public and Municipal Finance" } \\
\hline ISSN PRINT & \multicolumn{2}{|l|}{$2222-1867$} \\
\hline ISSN ONLINE & \multicolumn{2}{|l|}{ 2222-1875 } \\
\hline PUBLISHER & \multicolumn{2}{|c|}{ LLC "Consulting Publishing Company "Business Perspectives" } \\
\hline FOUNDER & \multicolumn{2}{|c|}{ LLC "Consulting Publishing Company "Business Perspectives" } \\
\hline $0^{\circ}$ & 18 & 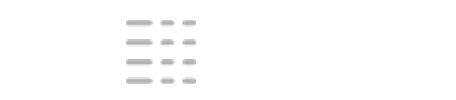 \\
\hline NUMBER OF REFERENCES & NUMBER OF FIGURES & NUMBER OF TABLES \\
\hline 11 & 6 & 4 \\
\hline
\end{tabular}

(C) The author(s) 2022. This publication is an open access article. 


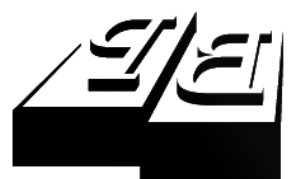

BUSINESS PERSPECTIVES

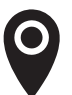

LLC "CPC "Business Perspectives" Hryhorii Skovoroda lane, 10, Sumy, 40022, Ukraine

www.businessperspectives.org

Received on: $19^{\text {th }}$ of October, 2018 Accepted on: $29^{\text {th }}$ of November, 2018

(C) Limited Liability Company "Consulting Publishing Company

"Business Perspectives", 2018

Nataliya Vyhovska, Doctor of Economics, Professor, Head of the Department of Finance and Credit, Zhytomyr State Technological University, Ukraine.

Andrii Polchanov, Ph.D., Associate Professor, Finance and Credit Department, Zhytomyr State Technological University, Ukraine.

Serhii Frolov, Ph.D. Student, University of Customs and Finance, Ukraine.

Yevhenii Kozmenko, Mgr., Sumy State University, Ukraine.
Nataliya Vyhovska (Ukraine), Andrii Polchanov (Ukraine), Serhii Frolov (Ukraine), Yevhenii Kozmenko (Ukraine)

THE EFFECT

OF IT-TRANSFORMATION OF THE COUNTRY'S FINANCIAL POTENTIAL DURING THE POSTCONFLICT RECONSTRUCTION

\begin{abstract}
Over the last five years, Ukraine suffers from armed conflicts that cause substantial losses in the state budget. In this context, shaping the prospects and developing measures for the post-conflict reconstruction of the state and its economy is an important problem. The very possibility and the effectiveness of such measures will depend on the country's financial potential as well as on the financial strength of its entities. This potential is dynamic and influenced by information technology, without which any institution cannot go.

Given the particular significance of the financial potential IT-transformation, the role of digital forms of money, crowdfunding and initial coin offering (ICO) was identified. It is substantiated that while overcoming the consequences of military conflicts, their implementation facilitates the attraction and acceleration of the financial resources movement. By generalizing the developments and practical experience of Ukrainian fintech-companies, the principles of such developments application for assessing the external financial environment of economic entities and conducting financial analysis have been shaped.
\end{abstract}

Keywords

JEL Classification military conflict, financial potential, digital forms of money, crowdfunding, ICO, Ukraine

\section{INTRODUCTION}

The prospects for post-conflict reconstruction under the influence of IT transformation of financial potential have gain interest due to several reasons:

- the first is the need for new forms of financial provision to overcome the consequences of fighting. These forms should complement traditional ways of mobilizing funds and reduce the burden on the budget, which mainly finances post-conflict activities;

- the second reason is driven by significant changes in the IT implementation in the financial sector;

- the third is due to the high level of the IT sector development and competitiveness. However, as a result of circumstances, the most of this sector participants focus not on the creation of their own products, but on outsourcing business processes for companies in the EU and North America. Subject to appropriate incentives by the state, this sector can play a significant role in post-conflict recovery, providing a truly innovative breakthrough for the economy. 


\section{THEORETICAL BACKGROUND}

One of the key publications about the IT role in overcoming the consequences of military conflicts is the research by the World Bank Group's staff, "The Role of Information and Communication Technologies in Postconflict Reconstruction" (Souter \& Kelly, 2013). Based on the World Bank experience, the article discloses the role of information technology in overcoming the consequences of military conflicts in Afghanistan, Liberia, Rwanda, East Timor and Tunisia. Also noteworthy is the work "Peacekeeping's Digital Economy: The role of communication technologies in post-conflict economic growth" (Martin-Shields \& Bodanac, 2017). Using African countries as an example, it has substantiated the model of the impact of investment in information technology on long-term economic development in post-conflict conditions.

The following articles are devoted to changing the role of the central bank in response to the digital transformation of money influenced by information technology: "Central bank cryptocurrencies" by Bech and Garratt (2017) specifies the content and the place of central bank cryptocurrencies in the general classification of forms of money; "Central Bank Digital Currency and the Future of Monetary Policy" (Bordo \& Levin, 2017) considers the prospects for the introduction and regulation of circulating the central bank's digital currencies (the authors did not restrict themselves to only blockchain technology); and "Digital currencies, decentralized ledgers, and the future of central banking" (Raskin \& Yermack, 2016) analyzes the new role of the central bank in the digital era. Chohan (2017), Kaal and Dell'Erba (2017), Rohr and Wright (2017), Zetzsche et al. (2017) and others discussed the prospects for using the new form of ICO (Initial Coin Offering) financing, which is inextricably linked with cryptocurrencies. At the same time, the prospects for using innovative forms of financing for the needs of the post-conflict recovery were not given due attention.

The purpose of the study is to determine the priority directions of transforming the state's financial potential through the IT introduction for the purposes of overcoming the military conflict consequences.

\section{RESULTS}

Defining the economic sense of the "financial potential" category remains rather controversial in the academic community. Along with that, in the most general sense, it is defined as the financial resources of a particular entity (it is the state in our case) and the possibilities for their effective development, distribution and usage with a certain purpose.

It should be noted that there are certain differences between the financial potential development of the state influenced by information technology in the context of post-conflict environment and in non-military conditions. These differences are as follows:

1) There is growing importance of financial resources from international financial institutions and developed countries, where the IT development is higher than in post-conflict states, and therefore may provide an additional incentive for their more active implementation in the financial sector. Under normal (peaceful) conditions, foreign donors' assistance and investment are not of so great importance and have not an impact on economic development.

2) In peacetime, the use of information technology is aimed more at improving existing financial products, for example, in terms of a more in-depth risk assessment, while in a post-conflict environment there is an opportunity not only to create, but also to actively use qualitative new ways to meet financial needs, in particular those affected by the conflict between private individuals, business and government.

Restoring infrastructure is one of the priority directions of state policy in the post-conflict period, in particular restoring the access to electricity, which is critical for the modern economy (Table 1). The lowest access is in Cambodia, Liberia, and Sierra Leone.

Nowadays, given the analysis results of this indicator's values in 216 countries during 2007-2016, the level of access to this kind of energy can be argued to be quite high (Figure 1). 
Table 1. Access to electricity in selected post-conflict countries, $\%$ of population

Source: The World Bank Group database.

\begin{tabular}{|c|c|c|c|c|c|c|c|c|c|c|}
\hline Country & Year 1 & Year 2 & Year 3 & Year 4 & Year 5 & Year 6 & Year 7 & Year 8 & Year 9 & Year 10 \\
\hline Angola & 39.75 & 39.07 & 38.39 & 37.71 & 37.50 & 36.41 & 35.77 & 35.13 & 34.60 & 33.88 \\
\hline Cambodia & 0.55 & 2.74 & 4.92 & 7.09 & 9.24 & 18.67 & 13.50 & 16.60 & 17.69 & 19.78 \\
\hline Congo & 28.61 & 29.63 & 30.65 & 31.65 & 32.66 & 33.80 & 34.70 & 35.73 & 36.78 & 37.10 \\
\hline Croatia & 100.00 & 100.00 & 100.00 & 100.00 & 100.00 & 100.00 & 100.00 & 100.00 & 100.00 & 100.00 \\
\hline Liberia & 0.07 & 0.29 & 0.80 & 3.00 & 2.58 & 1.90 & 4.75 & 4.10 & 6.94 & 9.80 \\
\hline Macedonia & 96.89 & 97.41 & 97.93 & 98.46 & 99.00 & 99.44 & 99.77 & 99.94 & 99.99 & 100.00 \\
\hline Serbia & 99.47 & 100.00 & 99.93 & 99.99 & 100.00 & 100.00 & 100.00 & 100.00 & 100.00 & 100.00 \\
\hline Sierra Leone & 15.93 & 15.66 & 16.80 & 15.12 & 14.87 & 14.62 & 12.10 & 14.16 & 13.94 & 14.20 \\
\hline Solomon Islands & 16.73 & 18.53 & 14.40 & 12.90 & 24.00 & 21.15 & 27.69 & 29.54 & 31.40 & 44.70 \\
\hline Tajikistan & 98.19 & 97.00 & 98.41 & 98.51 & 99.00 & 100.00 & 98.76 & 99.30 & 98.94 & 99.05 \\
\hline Georgia & 99.86 & 99.91 & 99.95 & 100.00 & 99.99 & 100.00 & $\mathrm{n} / \mathrm{a}$ & $\mathrm{n} / \mathrm{a}$ & $\mathrm{n} / \mathrm{a}$ & $\mathrm{n} / \mathrm{a}$ \\
\hline Indonesia & 90.62 & 91.10 & 92.73 & 93.55 & 94.15 & 94.83 & 96.00 & 96.46 & 97.01 & $\mathrm{n} / \mathrm{a}$ \\
\hline
\end{tabular}

Note: Years after the end of the conflict are indicated: Angola (2003), Indonesia (2006), Cambodia (1993), Liberia (2004), Macedonia (2002), the Republic of the Congo (2000), Serbia (2001), Solomon Islands (2004), Sierra Leone (2002), Tajikistan (1998), Croatia (1996).

Source: The World Bank Group database.

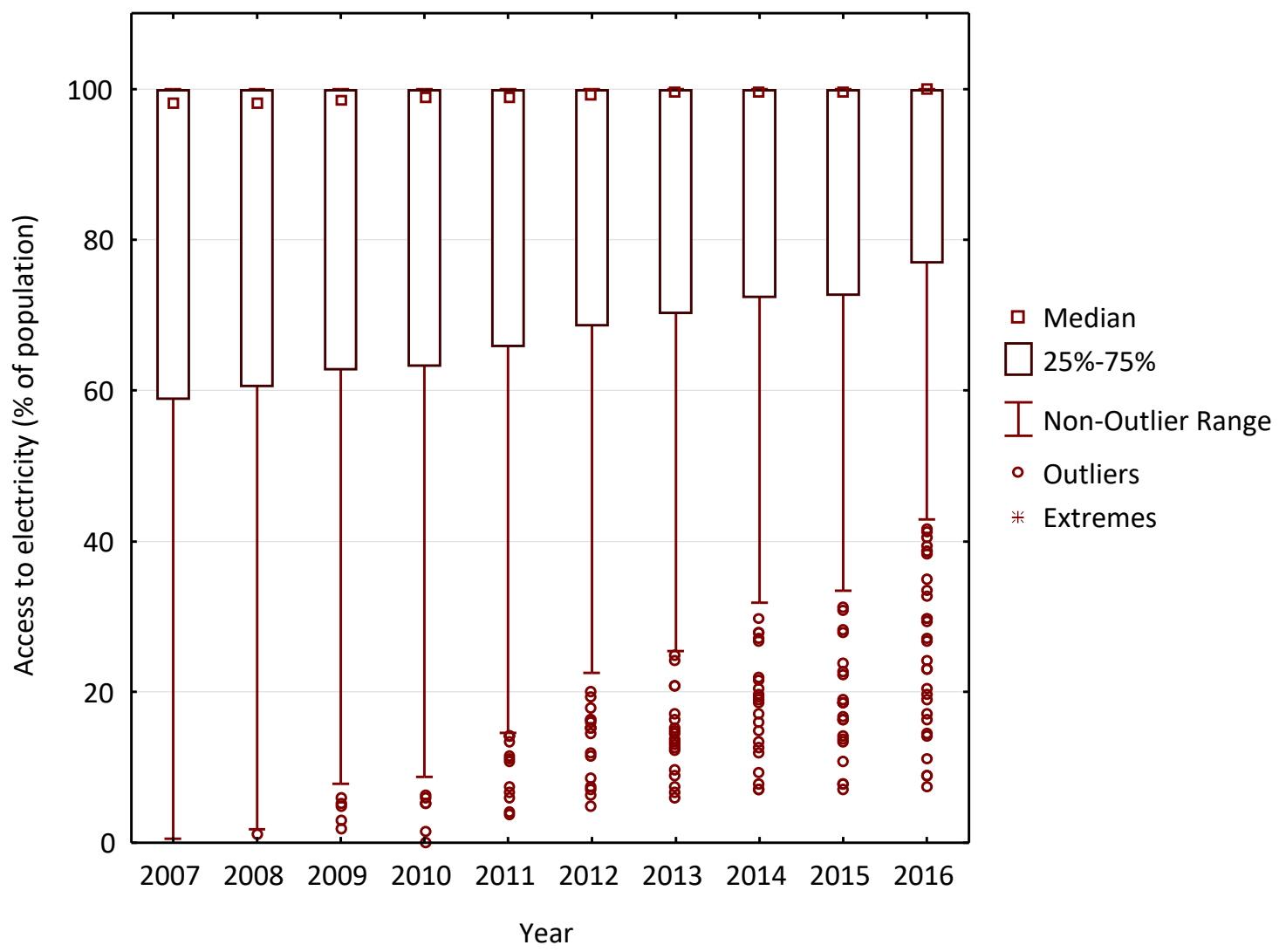

Figure 1. Access to electricity throughout the world in $2007-2016, \%$ of population 
Table 2. Internet users in selected post-conflict countries, \% of population

Source: The World Bank Group database.

\begin{tabular}{|c|c|c|c|c|c|c|c|c|c|c|}
\hline Country & Year 1 & Year 2 & Year 3 & Year 4 & Year 5 & Year 6 & Year 7 & Year 8 & Year 9 & Year 10 \\
\hline Georgia & 20.07 & 26.90 & 31.52 & 36.94 & 43.30 & 44.00 & 47.57 & $\mathrm{n} / \mathrm{a}$ & $\mathrm{n} / \mathrm{a}$ & $\mathrm{n} / \mathrm{a}$ \\
\hline Angola & 0.37 & 0.46 & 1.14 & 1.50 & 1.70 & 1.90 & 2.30 & 2.80 & 3.10 & 6.50 \\
\hline Congo & 0.03 & 0.03 & 0.16 & 0.46 & 1.08 & 1.46 & 2.01 & 2.76 & 4.29 & 4.50 \\
\hline Croatia & 0.86 & 1.73 & 3.27 & 4.41 & 6.64 & 11.56 & 17.76 & 22.75 & 30.91 & 33.14 \\
\hline Indonesia & 4.76 & 5.79 & 7.92 & 6.92 & 10.92 & 12.28 & 14.52 & 14.94 & 17.14 & 21.98 \\
\hline Liberia & 0.03 & $\mathrm{n} / \mathrm{a}$ & $\mathrm{n} / \mathrm{a}$ & 0.55 & 0.53 & 2.00 & 2.30 & 2.50 & 2.60 & 3.20 \\
\hline Macedonia & 17.33 & 19.07 & 24.44 & 26.45 & 28.62 & 36.30 & 46.04 & 51.77 & 51.90 & 56.70 \\
\hline Sierra Leone & 0.18 & 0.19 & 0.20 & 0.22 & 0.23 & 0.24 & 0.25 & 0.26 & 0.58 & 0.90 \\
\hline Solomon Islands & 0.65 & 0.84 & 1.65 & 2.00 & 3.00 & 4.00 & 5.00 & 6.00 & 7.00 & 8.00 \\
\hline
\end{tabular}

Note: Years after the end of the conflict are indicated: Angola (2003), Indonesia (2006), Cambodia (1993), Liberia (2004), Macedonia (2002), the Republic of Congo (2000), Serbia (2001), Solomon Islands (2004), Sierra Leone (2002), Tajikistan (1998), Croatia (1996).

In selected post-conflict countries, high Internet penetration can also be observed (Table 2), which corresponds to the global trend (Figure 2).

The increase in mobile cellular subscribers, which accelerates the data exchange and increases the number of financial decisions taken is an equally important factor in the high IT implementation in the economic sphere. The dynamics of the change in the number of mobile cellular subscribers (per 100 people) in post-conflict countries and throughout the world is presented in Table 3 and Figure 3. It should be noted that in developing countries, an excess of the number of subscribers and the population can be observed, which is due to the simultaneous use of several channels to access this mode of communication.

The prospects for the IT transformation of the financial potential to overcome the consequences of the military conflict in Ukraine are subject to a

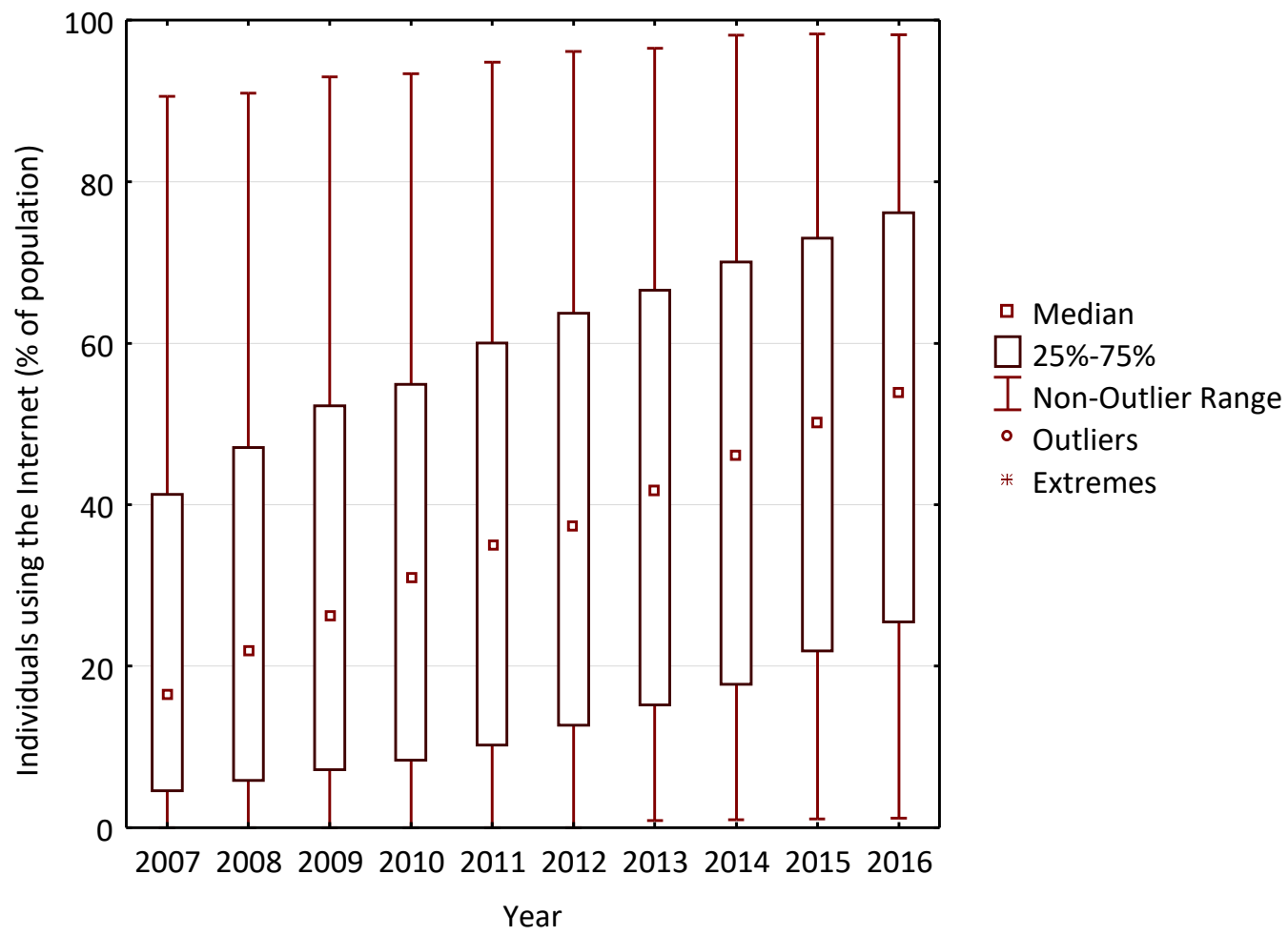

Figure 2. Internet users throughout the world in $2007-2016, \%$ of population 
Table 3. Mobile cellular subscribers (per 100 people) in selected post-conflict countries

Source: The World Bank Group database.

\begin{tabular}{|c|c|c|c|c|c|c|c|c|c|c|}
\hline Country & Year 1 & Year 2 & Year 3 & Year 4 & Year 5 & Year 6 & Year 7 & Year 8 & Year 9 & Year 10 \\
\hline Georgia & 64.46 & 90.65 & 101.28 & 107.81 & 115.03 & 124.94 & 128.95 & $\mathrm{n} / \mathrm{a}$ & $\mathrm{n} / \mathrm{a}$ & $\mathrm{n} / \mathrm{a}$ \\
\hline Angola & 2.27 & 4.63 & 9.74 & 17.84 & 28.01 & 36.98 & 42.85 & 48.10 & 59.83 & 61.41 \\
\hline Cambodia & 0.05 & 0.10 & 0.13 & 0.21 & 0.29 & 0.52 & 0.75 & 1.07 & 1.79 & 2.99 \\
\hline Congo & 2.24 & 4.68 & 6.75 & 9.81 & 11.12 & 15.76 & 25.16 & 34.26 & 46.61 & 73.80 \\
\hline Croatia & 1.40 & 2.62 & 4.01 & 6.54 & 23.08 & 39.47 & 52.25 & 57.52 & 64.45 & 83.16 \\
\hline Indonesia & 28.02 & 40.43 & 60.01 & 68.92 & 87.79 & 102.46 & 114.22 & 125.36 & 128.78 & 132.35 \\
\hline Liberia & 2.96 & 4.89 & 8.27 & 15.98 & 23.27 & 28.39 & 39.70 & 49.53 & 56.79 & 59.40 \\
\hline Macedonia & 17.61 & 37.29 & 47.25 & 54.11 & 60.36 & 85.59 & 93.75 & 92.51 & 102.44 & 105.20 \\
\hline Sierra Leone & 1.49 & 2.40 & $\mathrm{n} / \mathrm{a}$ & $\mathrm{n} / \mathrm{a}$ & $\mathrm{n} / \mathrm{a}$ & 14.33 & 18.24 & 20.56 & 34.77 & 36.43 \\
\hline Solomon Islands & 0.66 & 1.28 & 1.46 & 2.21 & 5.96 & 9.71 & 21.94 & 51.09 & 54.98 & 57.57 \\
\hline Tajikistan & 0.01 & 0.01 & 0.02 & 0.03 & 0.21 & 0.73 & 2.03 & 3.89 & 30.92 & 29.99 \\
\hline
\end{tabular}

Note: Years after the end of the conflict are indicated: Angola (2003), Indonesia (2006), Cambodia (1993), Liberia (2004), Macedonia (2002), the Republic of Congo (2000), Serbia (2001), Solomon Islands (2004), Sierra Leone (2002), Tajikistan (1998), Croatia (1996)

high share of population with Internet access that is more than global and closer to the EU level, as well as to the number of mobile cellular subscribers (per 100 people), which for several years have exceeded both the global indicators and the value of indicators in the EU. It is precisely due to the digital economy intensification, the development of the affected regions and the entire country is fostered.
The close attention of the world community to the bitcoin phenomenon led the highest-level leaders of many countries and international organizations to examine in depth the possibilities of using the blockchain technology to achieve their goals.

At the beginning of 2017, the UN World Food Program (WFP) within the "Building Blocks" pro-

Source: The World Bank Group database.

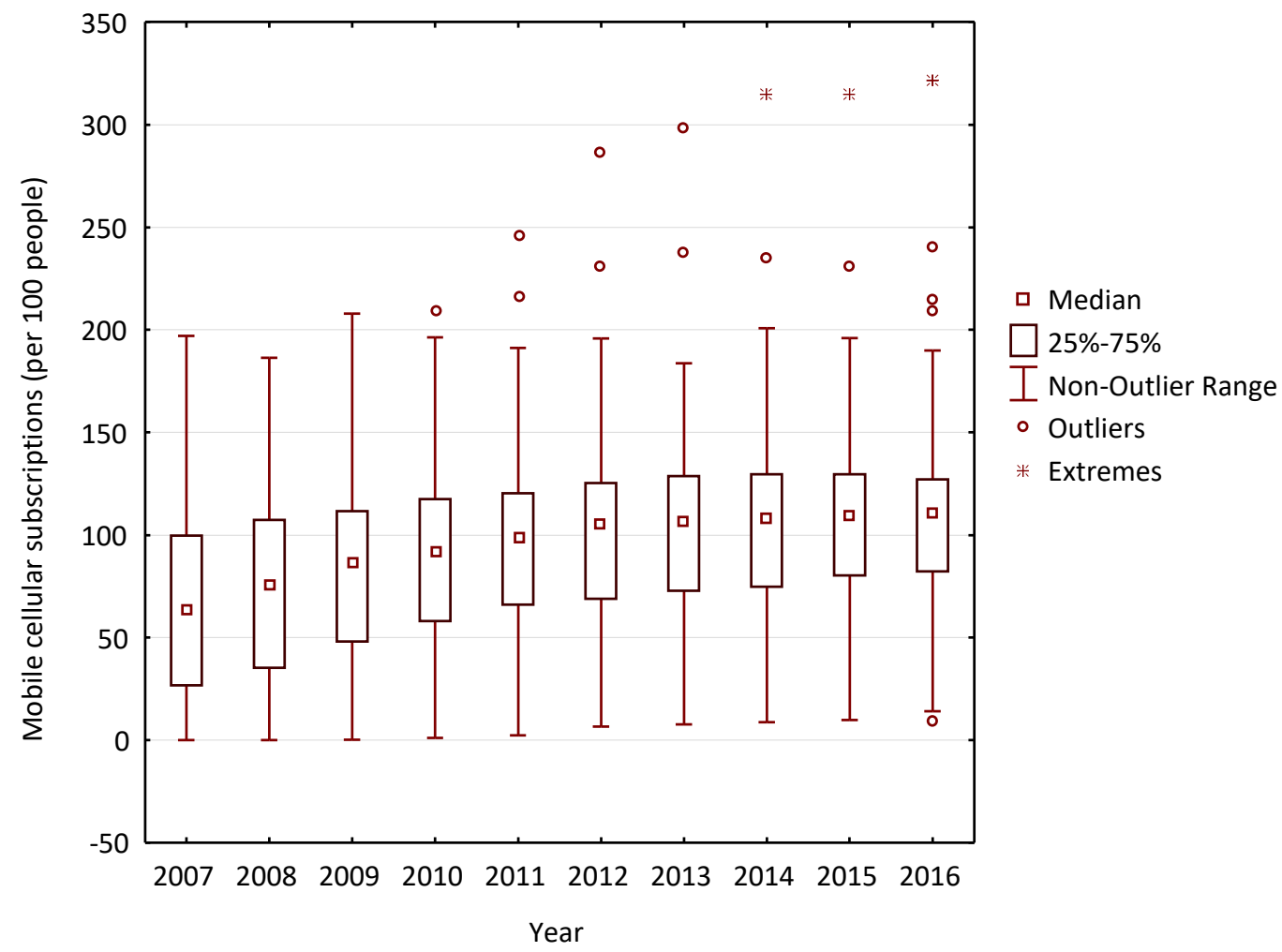

Figure 3. Mobile cellular subscribers (per 100 people) 
ject tested out the possibilities of the blockchain technology. There was the transfer of funds for the purchase of WFP products to low-income population in Pakistan using a mobile application built upon the Ethereum platform ("What is "blockchain' and how is it connected to fighting hunger?", 2017). Subsequently, this technology was tested at a Syrian refugees camp in Azraq, Jordan. This allowed the WFP to save 150 thousand dollars a month, reducing bank fees by $98 \%$ (Tirone, 2018).

Over a period of several years, the National Bank of Ukraine has been working on the introduction of a national currency based on the blockchain technology (e-hryvnia) provided for by the Comprehensive Program of Ukrainian Financial Sector Development Until 2020 and focused on reducing transaction costs and increasing the speed of money transfer. Given the official nature of information on the project implementation details, it is difficult to predict the specific features of e-hryvnia.

The Bank of Canada and the Bank of Sweden, the central banks of the countries with the lowest levels of cash in the world (up to 5\% of GDP), have become the most successful in implementing the digital version of the national currency: CADcoin (Canada) and eKrona (Sweden). The People's Bank of China reported about the testing of the prototype of its own digital money. It should be noted that it is in this country that the opportunities of developing this form of money look one of the greatest. This is important given the problems with access to traditional banking services for millions of rural citizens, the number of probable users and the aggregate power of the country's computer network, which dominates the field of mining globally.

In the authors' opinion, the launch of e-hryvnia in Ukraine should be strategically focused on the circulation of goods and services in the field of e-commerce, because in this case, the cost of such a payment instrument will be supported by the demand for such a form of money from the digital economy.

In summary, the introduction of e-hryvnia can have a significant positive impact on the domestic economic recovery, and also makes it possible to identify new threats (Figure 4).

First, e-hryvnia will facilitate the rapid restoration of trade and economic relations in areas affected by the conflict, as providing the Internet coverage and mobile networks is easier than restoring an appropriate banking infrastructure in the region.

\section{E-HRYVNIA}
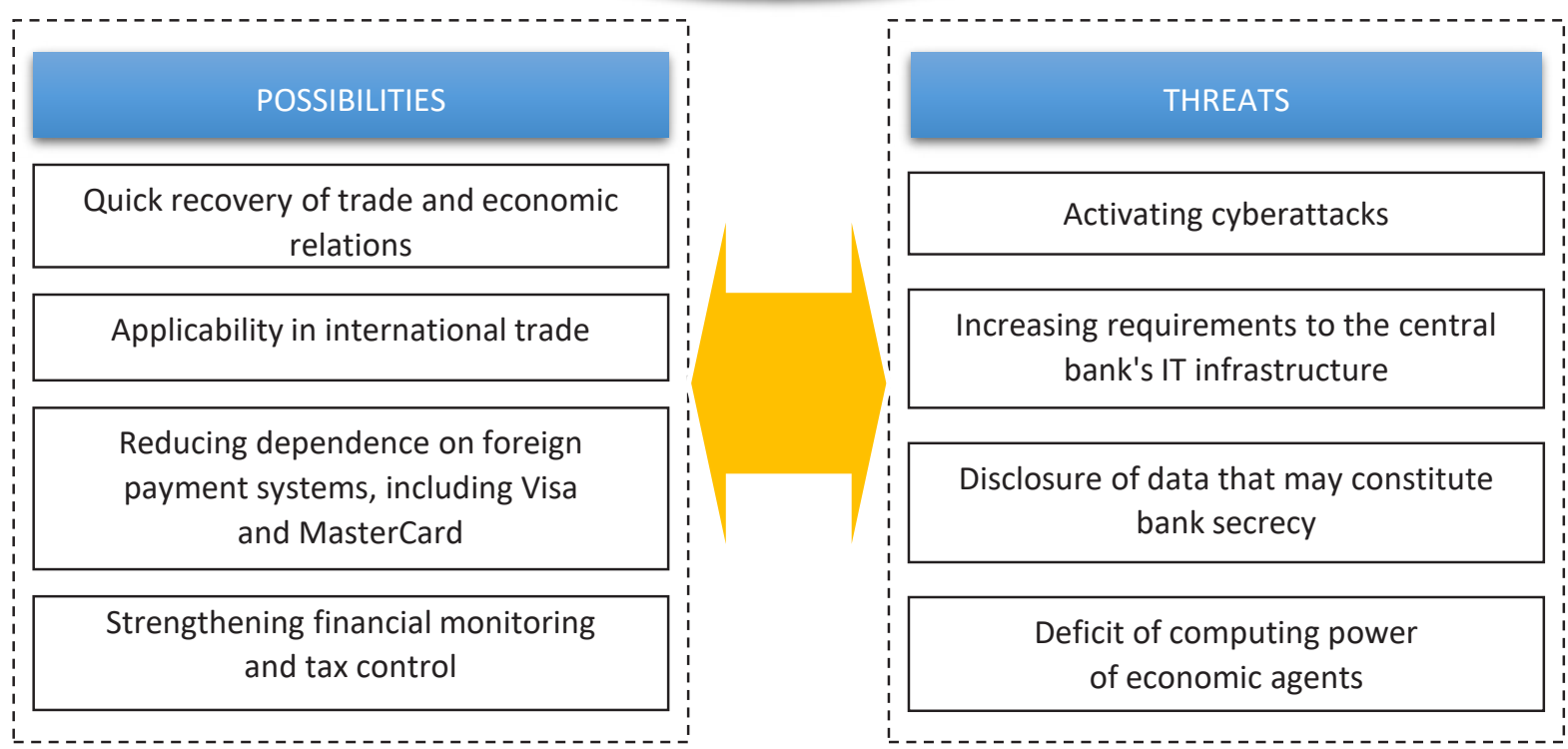

Figure 4. Position of e-hryvnia in the post-conflict economic reconstruction 
Second, given the low transaction costs, along with the speed of transactions, e-hryvnia can squeeze out individual cyber currencies and currency units of other countries as payment instruments, especially in the foreign economic activity of domestic business.

Third, such an event will have a positive impact on national financial security in terms of reducing dependence on foreign payment systems, in particular, Visa and MasterCard.

Fourth, the state will be able to strengthen the opportunities in tax control and financial monitoring, especially in terms of countering the terrorism financing.

On the other hand, it is quite expected that the requirements for the IT-infrastructure of the National Bank of Ukraine will be increased to provide payments, as well as the cyberattacks will become more intense. This will require an appropriate level of information systems security. At the same time, it will be important to achieve a compromise between the reliability and ease of the system operation. Along with this, there may be a lack of technical means in some economic agents for the proper functioning of e-hryvnia. Also one should not ignore possible disclosure of data that may constitute banking secrecy, which will require a certain regulation.

In general, the lack of clear state control over using innovative forms of financing in Ukraine imposes certain limitations on their possibilities. For example, in the Republic of Belarus, the Decree "On the Digital Economy Development" was signed at the end of 2017, which was the impetus for developing other legislative acts, in particular the National Standard of Accounting and Reporting "Digital Signs (tokens)".

Along with the issue of a new form of national monetary unit, it is possible to attract financial resources by issuing securities cryptocurrency-denominated. If the state, as an issuer, considers this option unlikely under normal market conditions (but it may well be implemented in countries subject to sanctions, for example in Venezuela), then for e-business subjects, in particular those that can generate cash flow in cryptocurrency, this idea is quite promising.
It is the development of blockchain technology and related cryptocurrency distribution that contributed to another innovative form of financing ICO. This term has appeared quite recently and, according to crypto-market participants, serves as the analog for the IPO (Initial Public Offering), the traditional way of raising capital by joint-stock companies.

While systematizing the views of scientists and practitioners, a generalized algorithm for raising funds during an ICO can be presented (Figure 5).

A company, or a project team, that has a specific idea requiring funding, outlines its business proposal, business plan, and technical documentation at Whitepaper, a document acting as a prospectus for IPOs, and defines the issuer's liabilities and investor's rights.

Interested investors can invest money by converting them into cryptocurrency (usually Bitcoin and Ethereum are the most liquid cryptocurrencies on the market). With the help of a smart contract (a computer protocol that, based on mathematical algorithms, independently conducts fully controlled operations), the cryptocurrency-token exchange is carried out. Tokens are digital signs issued by the company certifying its duties to the investor and providing the latter with the corresponding rights.

Due to smart contracts, there is no need for intermediaries to accompany the deal, such as underwriters, legal and audit companies, which reduces capital spending and facilitates access for small and medium-sized businesses.

The ICO in its content is similar to crowdfunding, which involves the collective financing of certain projects at the expense of voluntary contributions. The rapid development of crowdfunding is due to the Internet spread and switching financing of non-commercial projects (recording a music album, filming, writing a book) to startups or the development of an existing business. Compared to the ICO, this form of financing has more examples of successful fundraising. "Spilnokosht", "NA-STARTE", and "GoFundEd" are among the popular Ukrainian crowdfunding platforms. 


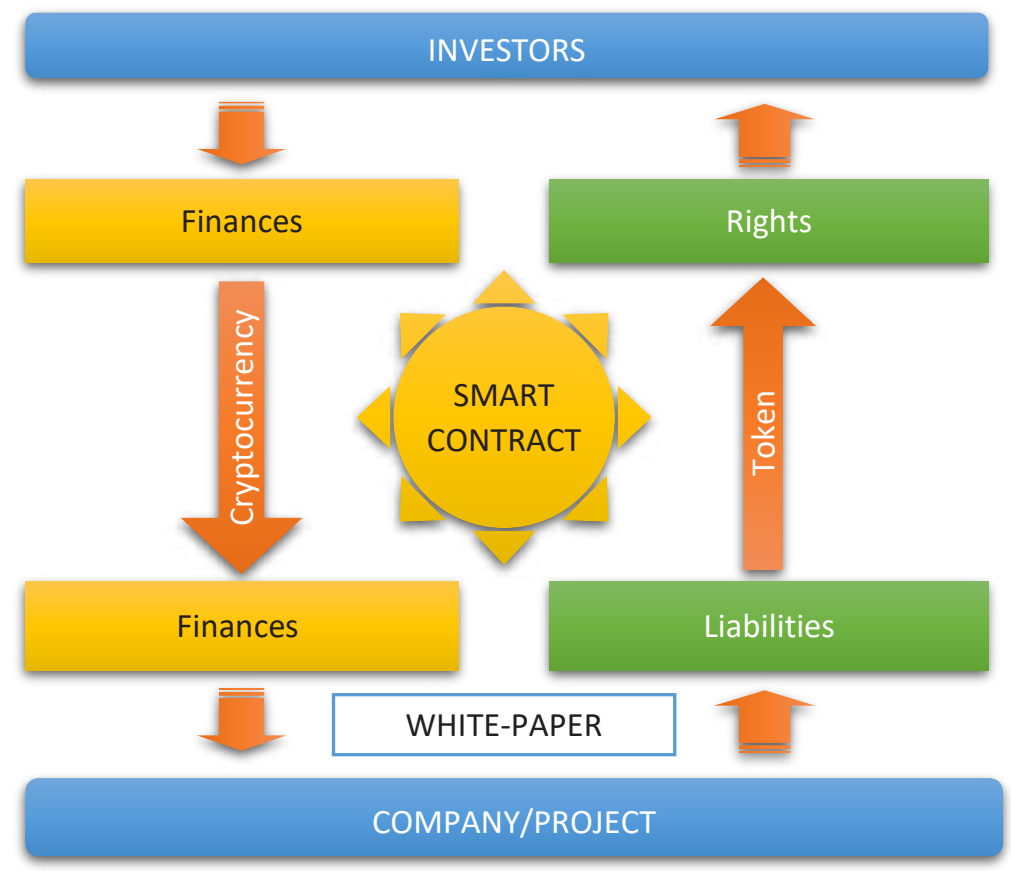

Figure 5. Generalized algorithm for attracting funding during the ICO

Thanks to information technology, significant progress has been made in improving the business environment assessment. In this context, two areas should be distinguished:

1) a detailed assessment of the external financial environment based on the open data analysis (for example, the state register of court decisions, information from the securities market, etc.); and

2) an in-depth internal financial analysis based on the integration of various corporate information systems and big data analysis.

Table 4 shows services that are already offered by domestic fintech companies in this area and that will maybe require stepped-up supervision by the state regulator.

As can be seen from Table 4, services related to the assessment of the external financial environment are offered by various predefined packages (YouControl, Alfa Protection, SkyService), while the cost of services focused on internal analysis depends on the specific customer and his business unique features.

Given the devaluation of the national currency in recent years, the cost of foreign companies service has been ignored, as they are usually designed for the needs of companies from the European Union and North America, and are much more expensive. At the same time, emerging such IT projects in countries that eliminate the consequences of military conflicts looks promising.

In general, the study results suggest that the IT development, which led to the transformation of financial capacity, has resulted in innovative forms of financing and improvement of existing approaches to the financial environment assessment, the use of which, in turn, can accelerate the overcoming of the military conflict consequences (Figure 6).

In order to increase the efficient use of financial capabilities, creation of a body that would coordinate actions of various government departments, businesses and international partners of Ukraine looks promising. Therefore, the establishment of the Investment Attraction Center seems to be possible, the priority tasks of which are as follows:

- creating a platform for the integration of crowdfunding platforms, cryptocurrency exchanges and tokens, which plan to take part in attracting financial resources to stimulate socio-economic development of both a conflict zone (which will be preferred) and a whole country; 
Tables 4. Services of domestic fintech companies on improving the assessment of the business financial environment

Source: Compiled by the authors based on the analysis of related companies' sites.

\begin{tabular}{|c|c|c|c|c|}
\hline No. & $\begin{array}{c}\text { Company (year of } \\
\text { establishment) }\end{array}$ & Services & Target audience & Service cost \\
\hline 1 & $\begin{array}{l}\text { Corezoid } \\
(2014)\end{array}$ & $\begin{array}{l}\text { Combining software into a software } \\
\text { digital core with unified interfaces and } \\
\text { analytics }\end{array}$ & $\begin{array}{l}\text { Banks and non-bank financial } \\
\text { institutions, television } \\
\text { companies }\end{array}$ & $\begin{array}{l}\text { USD } 300 \text { and } \\
\text { more per annum }\end{array}$ \\
\hline 2 & $\begin{array}{l}\text { Bintels } \\
(2017)\end{array}$ & $\begin{array}{l}\text { Business analytics development and data } \\
\text { visualization }\end{array}$ & $\begin{array}{l}\text { Mid-sized business that } \\
\text { generates a large amount of } \\
\text { data }\end{array}$ & $\begin{array}{l}\text { Depends on the } \\
\text { customer }\end{array}$ \\
\hline 3 & Smart Data (2014) & $\begin{array}{l}\text { In-depth customer analytics based on } \\
\text { data mining and risk management }\end{array}$ & Business in a B2C segment & $\begin{array}{l}\text { Depends on the } \\
\text { customer }\end{array}$ \\
\hline 4 & $\begin{array}{l}\text { Team301 } \\
(2016)\end{array}$ & $\begin{array}{l}\text { Business process optimization and } \\
\text { modeling customer behavior }\end{array}$ & Business in a B2C segment & $\begin{array}{l}\text { Depends on the } \\
\text { customer }\end{array}$ \\
\hline 5 & YouControl (2014) & $\begin{array}{l}\text { Checking counterparties with the } \\
\text { capabilities of complex business analytics }\end{array}$ & Business with a lot of customers & $\begin{array}{l}\text { UAH 25,000 per } \\
\text { annum }\end{array}$ \\
\hline 6 & Alfa Protection (2017) & $\begin{array}{l}\text { Counterparty analysis based on Machine } \\
\text { Learning, Device Fingerprint and Rule } \\
\text { Engine }\end{array}$ & Mid-sized and big business & $\begin{array}{l}\text { USD } 168 \text { and } \\
\text { more per annum }\end{array}$ \\
\hline 7 & SkyService (2015) & $\begin{array}{l}\text { Accounting and monitoring automation } \\
\text { supplemented by intelligent analytics }\end{array}$ & $\begin{array}{l}\text { Small and mid-sized business of } \\
\text { various areas }\end{array}$ & $\begin{array}{l}\text { UAH 2,388 per } \\
\text { annum }\end{array}$ \\
\hline
\end{tabular}

- detailed analysis of projects for financing aimed at economic rehabilitation of the affected regions and restoration of production, trade and financial relations;

- keeping a public register of such projects, indicating their managers, characteristics of their activities, project implementation status, funding involved and other information (in the long term, it is possible to use open data analysis to prevent fraud);

- information support in mass media and on social networks;

- intensive cooperation between the IT sector and the real sector of the economy representatives;

- coordination of activities with other authorities, in particular the Ministry of Temporarily Occupied Territories and Internally Displaced Persons of Ukraine (to assess the compliance of the project objectives with the strategic priorities of economic recovery); the National Bank of Ukraine (regarding the conducting an ICO with the cybercurrency issued to the latter); the Ministry of Foreign Affairs (on increasing the international community's interest in projects); the Ministry of Economic Development and Trade of Ukraine (in terms of identifying priority areas for reconstruction); and the Ministry of Education and
Science of Ukraine (regarding the training of relevant specialists and intensifying scientific research on the overcoming the consequences of fighting).

In addition, the Investment Attraction Center may ask relevant authorities to allocate budget funds for implementing recovery projects that have not received full financial support but are of significant public importance. In this case, the proportion of financial resources received from the state in the total amount of borrowed funds should be limited to prevent the effect of crowding out, when the increase in budget expenditures would reduce private investment.

The most important sectors of the economy that can ensure national competitiveness and socio-economic development in the long run include agriculture (including arable land and natural conditions), transport infrastructure (given the geography) and energy (through potential for increasing energy production from renewable sources).

For example, raising capital for the construction of toll roads through innovative forms of financing can be stimulated by providing preferences for their use to those who financially support the project. A similar situation may be with the collection of funds for the organic production development, according to which the implementation of cultivated products with a minimum extra charge may be provided. 


\section{IT DEVELOPMENT}

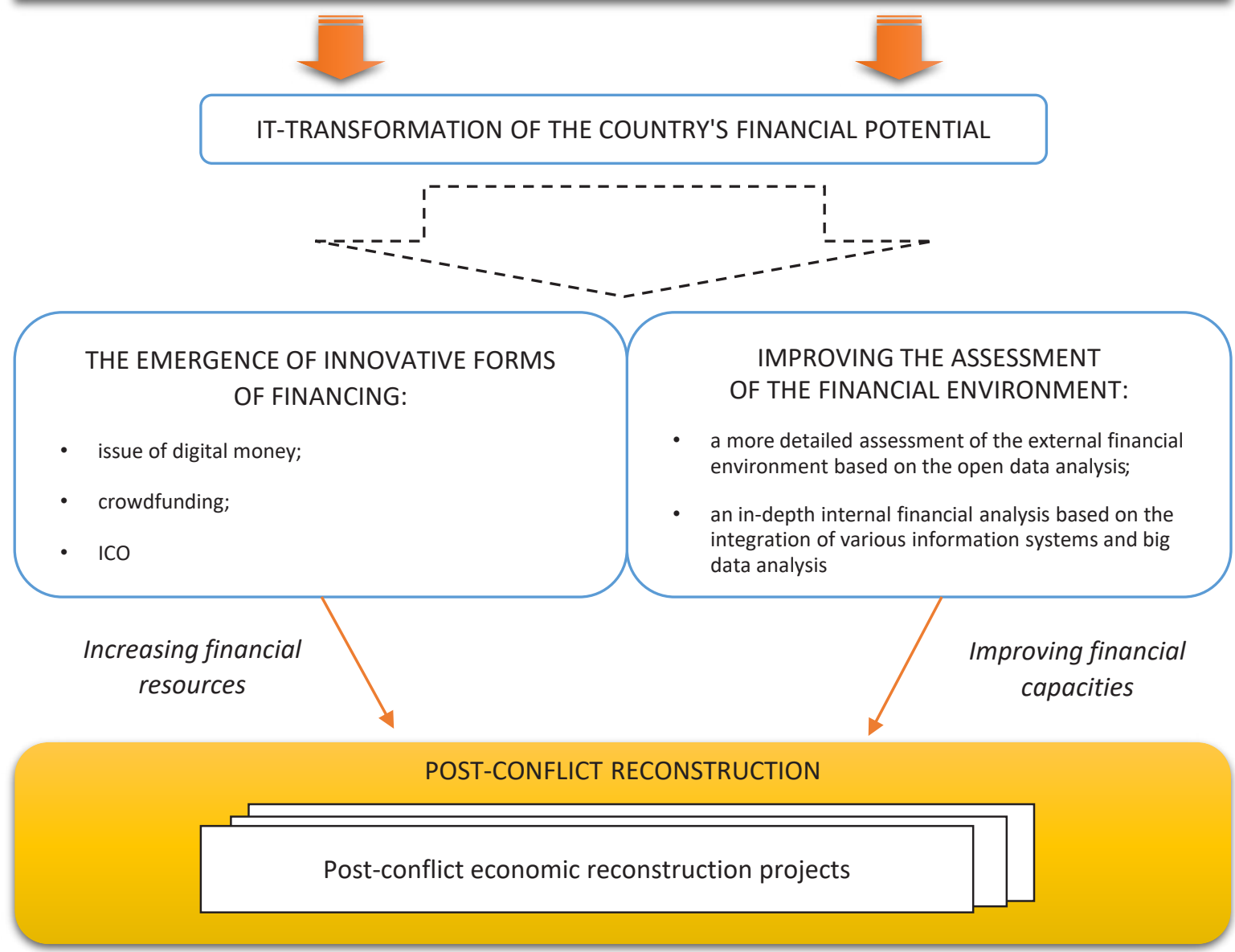

Figure 6. Priority areas of transforming the country's financial potential through the IT introduction in the context of overcoming the military conflict consequences

In general, the development of financial potential influenced by information technology can have a significant impact on raising capital to finance post-conflict reconstruction projects of individual regions and the economy as a whole as well as on the efficient use of financial resources mobilized.

\section{CONCLUSION}

IT transformation of the state's financial potential becomes of particular importance in overcoming the military conflict consequences, as it not only promotes the improvement of existing financial products from the standpoint of the post-conflict economy needs. It also contributes to the emergence of qualitatively new ways to solve financial problems facing economic agents.

The use of innovative forms of funding, such as digital money issue, crowdfunding, and ICO is one of the most promising ways to increase financial resources for post-conflict recovery projects. In addition, the introduction of information technology has made it possible to improve the assessment of the external and internal financial environment of business, thus contributing to the efficient movement of financial resources. 


\section{REFERENCES}

1. Bech, M. L., \& Garratt, R. (2017). Central Bank Cryptocurrencies. Retrieved from https://www.bis. org/publ/qtrpdf/r_qt1709f.htm

2. Bordo, M., \& Levin, A. (2017). Central Bank Digital Currency and the Future of Monetary Policy (No. w23711). National Bureau of Economic Research, Cambridge, MA. https://doi.org/10.3386/ w23711

3. Chohan, U. W. (2017). Initial Coin Offerings (ICOs): Risks, Regulation, and Accountability. SSRN Electronic Journal. https:// doi.org/10.2139/ssrn.3080098

4. Kaal, W. A., \& Dell'Erba, M. (2017). Initial Coin Offerings: Emerging Practices, Risk Factors, and Red Flags. SSRN Electronic Journal. https://doi.org/10.2139/ ssrn.3067615

5. Martin-Shields, C., \& Bodanac, N. (2017). Peacekeeping's
Digital Economy: The Role of Communication Technologies in Post-Conflict Economic Growth. SSRN Electronic Journal. https:// doi.org/10.2139/ssrn.2970923

6. Raskin, M., \& Yermack, D. (2016). Digital Currencies, Decentralized Ledgers, and the Future of Central Banking (No. w22238). National Bureau of Economic Research, Cambridge, MA. https://doi.org/10.3386/ w22238

7. Rohr, J., \& Wright, A. (2017). Blockchain-Based Token Sales, Initial Coin Offerings, and the Democratization of Public Capital Markets. SSRN Electronic Journal. https://doi.org/10.2139/ ssrn.3048104

8. Souter, D., \& Kelly, T. (2013). The Role of Information and Communication Technologies in Postconflict Reconstruction.

The World Bank. https://doi. org/10.1596/978-1-4648-0074-0

9. Tirone, J. (2018). Banks Replaced With Blockchain at International Food Program. Retrived from https://www.bloomberg.com/ news/articles/2018-02-16/banksreplaced-with-blockchain-atinternational-food-program

10. What is 'blockchain' and how is it connected to fighting hunger? (2017). Retrieved from https:// insight.wfp.org/what-is-blockchain-and-how-is-it-connectedto-fighting-hunger-7f1b42da9fe

11. Zetzsche, D. A., Buckley, R. P., Arner, D. W., \& FFhr, L. (2017). The ICO Gold Rush: It's a Scam, It's a Bubble, It's a Super Challenge for Regulators. SSRN Electronic Journal. https://doi. org/10.2139/ssrn.3072298 